\title{
Pengaruh Kurikulum 2013 pada Mata Pelajaran Pendidikan Agama Kristen terhadap Perkembangan Spiritual Anak Kelas 4 \& 5 SD Kristen Kalam Kudus Makassar
}

\section{The Influence of the 2013 Curriculum on Christian Religious Education Subjects on the Spiritual Development of Children in Grade 4 \& 5 of Kalam Kudus Christian Elementary School, Makassar}

\author{
Natalia Mallangi, ${ }^{1)^{*}}$ Ivan Th. J. Weismann ${ }^{2)^{*}}$ \\ 1) Mahasiswa Pascasarjana Sekolah Tinggi Filsafat Theologia Jaffray Makassar \\ *Penulis Korespondensi: nataliamallangi12@gmail.com \\ ${ }^{2)}$ Dosen Sekolah Tinggi Filsafat Theologia Jaffray Makassar \\ *Penulis Korespondensi: ivanweismann@yahoo.com
}

Received: 1408 2020/ Accepted: 1205 2021/ Published: 01062021

\begin{abstract}
Abstrak
Kurikulum adalah bagian yang penting dalam dunia pendidikan, maka kurikulum perlu untuk dirancang dengan baik dan disempurnakan. Di Indonesia, kurikulum telah mengelami beberapa kali perubahan. Adapun tujuan penulisan ini adalah untuk mengetahui pengaruh Kurikulum 2013 (K13) pada mata pelajaran Pendidikan Agama Kristen terhadap perkembangan spiritual anak kelas 4 \& 5 SD Kristen Kalam Kudus Makassar. Metode penelitian yang digunakan dalam penulisan ini adalah metode kuantitatif. Untuk melakukan peneltian tersebut hal yang dilakukan, yaitu: pertama, pengambilan dan pengumpulan data melalui buku, jurnal, dan artikel yang berkaitan dengan judul yang dibahas dalam tulisan. Kedua, penyebaran angket pada siswa-siswi SD Kristen Kalam Kudus Makassar. Ketiga, melakukan wawancara secara langsung kepada siswa-siswi. Berdasarkan hasil penelitian penulis maka: pertama, manajemen kurikulum 2013 yang dilaksanakan pada SD Kristen Kalam Kudus telah terlaksana dengan baik. Kedua, siswa-siswi yang menjadi responden pada penelitian ini berada pada tahap Conjunctive Faith dan Universalizing Faith, jadi hanya terdapat dua tahap dari enam tahap perkembangan spiritual. Ketiga, pengaruh antara variabel $X$ dan $Y$ berada pada korelasi yang lemah dengan konstribusi sebesar 0,07\% terhadap tahap Conjunctive Faith dan konstribusi sebesar 22\% terhadap tahap Universalizing Faith. Keempat, dari hasil wawancara yang dilakukan maka didapatkan bahwa faktor yang mendukung perkembangan spiritual pada responden adalah keluarga dan gereja.
\end{abstract}

Kata-kata Kunci: Guru, Kurikulum 2013, PAK, Perkembangan, Spiritual Anak. 


\begin{abstract}
The curriculum is an important part of education, so the curriculum needs to be well designed and perfected. In Indonesia, the curriculum has undergone several changes. The purpose of this paper is to determine the effect of the 2013 Curriculum (K13) on the subject of Christian Religious Education on the spiritual development of children in grades $4 \& 5$ of Kalam Kudus Christian Elementary School Makassar. The research method used in this writing is the quantitative method. To carry out this research, things were done: First, collecting and collecting data through books, journals, and articles related to the titles discussed in writing. Second, distributing questionnaires to students of Kalam Kudus Christian Elementary School Makassar. Third, conduct interviews directly with students. Based on the author's research results: First, the 2013 curriculum management implemented at Kalam Kudus Christian Elementary School has been implemented well. Second, the respondents in this study were at the Conjunctive Faith and Universalizing Faith stages, so there were only two stages out of the six stages of spiritual development. Third, the influence between variables $X$ and $Y$ is in a weak correlation with a contribution of $0.07 \%$ to the Conjunctive Faith stage and $22 \%$ to the Universalizing Faith stage. Fourth, from the interviews conducted, it was found that the factors that support the spiritual development of the respondents are family and church.
\end{abstract}

Keywords: 2013 Curriculum, Development, Spirituality of Children, Christian Religius Education, Teachers.

\title{
PENDAHULUAN
}

Pemahaman tentang pendidikan sangat memengaruhi berhasil atau tidaknya pendidikan yang dijalani oleh seseorang. Dalam pencapaian keberhasilan dalam pendidikan sangat diperlukan pemahaman yang benar mengenai pendidikan. Dalam membesarkan anak, tentu orangtua tidak hanya akan memperhatikan bagian fisik seorang anak tetapi juga akan memperhatikan pendidikannya. Banyak hal yang akan dilakukan orangtua agar anaknya memiliki pendidikan yang baik seperti: mempersiapkan biaya pendidikan, mencari sekolah yang tepat, dan lain sebagainya.

Undang-undang Republik Indonesia Nomor 20 Tahun 2003 tentang Sistem Pendidikan Nasional Bab I Pasal 1 Ayat 1, telah mengukuhkan bahwa proses pembelajaran diwujudkan untuk mengembangkan potensi peserta didik untuk memiliki kekuatan spiritual keagamaan (Supriyanto, 2016, p. 49). Sesuai dengan undang-undang, maka perlu diperhatikan pentingnya perkembangan spiritual. Di mana, setiap proses pembelajaran yang dilakukan harus mampu untuk mengembangkan spiritual anak. Mata pelajaran yang dapat menjadi jembatan penting untuk mencapai perkembangan spiritual anak adalah Pendidikan Agama 
Kristen. Spiritual menjadi cara atau kebiasaan yang dilakukan seorang hingga akhirnya menjadi karakter. Anak dengan spiritual yang tepat memungkinkan dirinya untuk tidak berperilaku negatif (Puspitasari, 2015, p. 409).

Pendidikan agama menuntun orang untuk menyadari apa yang telah ditemukan, berhubungan dengan apa yang telah ditemukan, dan bagaimana mengekspresikan hubungan itu. Setiap usaha pendidikan yang berusaha melakukan hal ini adalah dan seharusnya disebut pendidikan agama; pendidikan agama merupakan kegiatan yang kompleks (Groome, 2011, p. 37). Berbicara tentang kompleks berarti secara utuh, jadi dalam penerapannya pendidikan agama sangat penting untuk diperhatikan. "Didiklah orang muda menurut jalan yang patut baginya, maka pada masa tuanyapun ia tidak akan menyimpang dari pada jalan itu" (Amsal 22:6). Ayat ini jelas mengingatkan orangtua mau pun guru untuk menjalankan tugasnya dengan tepat sebagai pendidik ketika ingin melihat hasil yang terbaik dari anak.

Dengan demikian, untuk mencapai tujuan pendidikan maka dalam pendidikan diperlukan kurikulum. Kurikulum merupakan salah satu komponen pendidikan yang sangat strategis, karena merupakan seperangkat rencana dan pengaturan mengenai tujuan, isi, dan bahan pelajaran serta cara yang digunakan sebagai pedoman penyelenggaraan kegiatan pembelajaran untuk mencapai tujuan pendidikan tertentu. Atau dengan kata lain, kurikulum berfungsi sebagai inti dari proses di sekolah (Gunawan dan Benty, 2017, p. 198). Melihat kurikulum sebagai inti dari proses pendidikan, maka pendidikan tidak terlepas dari kurikulum.

Di Indonesia, sudah beberapa kali mengalami perubahan kurikulum. Perubahan ini disebut dengan pengembangan kurikulum, perkembangan kurikulum tentu disertai dengan tujuan pendidikan yang berbeda-beda karena dalam setiap perubahan yang terjadi ada suatu tujuan yang ingin dicapai untuk memajukan pendidikan. Seperti Kurikulum 1947, Kurikulum 1952, Kurikulum 1964, Kurikulum 1968, Kurikulum 1974, Kurikulum 1984, Kurikulum 1994, Kurikulum 2004, Kurikulum Tingkat Satuan Pendidikan (2006), dan sekarang Kurikulum 2013 (K13; Gunawan dan Benty, 2017, p. 201).

Perubahan kurikulum merupakan hal yang biasa terjadi demi memperbaiki kualitas pendidikan. Perubahan yang dilakukan bukan karena kemauan dari beberapa pihak dan tanpa tujuan. Kementerian Pendidikan dan Kebudayaan telah mempersiapkan proses penyusunan Kurikulum 2013 sejak 2010 dan hal tersebut merupakan salah satu upaya untuk memperbarui proses pendidikan sesuai dengan apa yang menjadi kebutuhan anak.

Dengan tujuan perubahan-perubahan kurikulum pada pendidikan di Indonesia dan pemilihan Kurikulum 2013 yang memiliki tujuan untuk mencetak siswa-siswi dengan potensi yang dimiliki maka tentu dalam perkembangan spiritual hal ini sangat mendukung. Kurikulum 2013 diharapkan bisa jadi alat bagi para pendidik untuk mencapai tujuan Pendidikan Agama Kristen secara khusus perkembangan spiritual anak. Di mana Pendidikan Agama Kristen sangat erat kaitannya dengan 
perkembangan spiritual. Ketika perkembangan spiritual anak sempurna maka tujuan Pendidikan Agama Kristen terwujud.

\section{TEORI}

\section{Manajemen Kurikulum}

Kurikulum memegang kedudukan sebagai kunci dalam pendidikan, karena berkaitan dengan penentuan arah, isi, dan proses dalam pendidikan yang pada akhirnya menentukan macam dan kualifikasi lulusan suatu lembaga pendidikan. Dalam dunia pendidikan, pembelajaran yang dilaksanakan oleh guru dan siswa merupakan inti dari pendidikan formal tersebut. Guru melakukan interaksi dengan siswa untuk membantu siswa dapat mengembangkan potensi yang dimilikinya. Dalam melaksanakan pembelajaran, guru harus menyiapkan rencana pembelajaran tertulis, tujuan pembelajaran, bahan pembelajaran yang disusun secara sistematis, dan dengan cara dan alat-alat yang dipilih dan dirancang secara cermat (Gunawan dan Benty, 2017, p. 230).

Sebelum membahas mengenai kurikulum, yang pertama menjadi perhatian adalah tujuan pendidikan khususnya di sekolah dasar. Tujuan pendidikan di sekolah dasar pada hakikatnya mengacu pada tujuan pendidikan nasional serta memperhatikan tahap karakteristik perkembangan peserta didik, kesesuaian dengan lingkungan dan kebutuhan pembangunan daerah, arah pembangunan nasional serta memperhatikan perkembangan ilmu pengetahuan dan teknologi dan kehidupan umat manusia. Perkembangan peserta didik pada masa antara umur 6-12 tahun merupkan masa subur dalam memompa potensi yang mereka miliki. Maka, arah tujuan pada tingkat ini harus benar-benar diperhatikan perkembangan minat dan bakat peserta didik (Ma'as, 2016, p. 11).

Oleh karena itu, kurikulum hadir dalam dunia pendidikan. Kurikulum merupakan bagian penting dalam proses pendidikan karena merupakan acuan utama dalam menjalankan proses pendidikan yang ada. Kurikulum 2013 merupakan kurikulum penyempurnaan dari kurikulum tingkat satuan pendidikan (KTSP) yang berlaku pada tahun 2006. Tentu saja ada berbagai macam pertimbangan yang menjadi acuan dalam merumuskan kurikulum 2013 ini, jadi bukan semata-mata tanpa dasar yang tidak dipertanggungjawabkan.

Perubahan kurikulum dari KTSP ke Kurikulum 2013 merupakan salah satu upaya untuk memperbarui dan setelah diadakannya penelitian untuk pengembangan kurikulum sesuai dengan kebutuhan generasi muda. Kurikulum 2013 merupakan kurikulum yang disiapkan untuk mencetak generasi yang siap di dalam menghadapi masa depan, oleh karena itu kurikulum ini disusun untuk mengantisipasi perkembangan masa depan. Titik berat dari kurikulum 2013 adalah untuk mendorong siswa agar mempu lebih baik dalam melakukan observasi, bertanya, bernalar, dan mengkomunikasikan (mempresentasikan), apa yang diperoleh atau diketahui setelah menerima materi pembelajaran (Gunawan dan Benty, 2017, p. 227). 
Dalam pengembangan Kurikulum 2013, ada beberapa faktor yang menjadi alasan terjadinya pengembangan, antara lain: pertama, adanya tantangan masa depan yang meliputi arus globalisasi, lingkungan hidup, kemajuan teknologi informasi, konvergensi ilmu dan teknologi, dan ekonomi berbasis pengetahuan. Kedua, mengenai kompetensi masa depan yang di antaranya meliputi kemampuan berkomunikasi, kemampuan berpikir, kemampuan mempertimbangkan suatu permasalahan, kemampuan menjadi warga negara yang efektif, dan kemampuan untuk mencoba untuk mengerti. Ketiga, adanya fenomena sosial yang mengemuka seperti perkelahian, pelajar, narkoba, korupsi, plagiarism, kecurangan, dan gejolak sosial. Keempat, adanya persepsi umum yang menilai pendidikan selama ini terlalu menitiberatkan pada aspek kognitif saja (Gunawan dan Benty, 2017, p. 229).

Setiap kurikulum memiliki karakteristik tersendiri, demikian pula dengan kurikulum 2013 yang juga memiliki karakakteristik, seperti: mengembangkan keseimbangan antara pengembangan sikap spiritual dan sosial, rasa ingin tahu, kreativitas, kerja sama dengan kemampuan intelektual dan psikomotorik; mengembangkan sikap, pengetahuan, dan keterampilan serta menerapkannya dalam berbagai situasi di sekolah dan masyarakat (Ma'as, 2016, p. 39).

Dalam kurikulum 2013, terdapat struktur yang harus diperhatikan oleh sekolah dalam menjalankan proses pembelajaran. Struktur kurikulum terdiri atas sejumlah mata pelajaran, beban belajar, dan kalender pendidikan. Dalam mata pelajaran yang harus diperhatikan yaitu: mata pelajaran wajib diikuti oleh seluruh siswa di satu satuan pendidikan dan mata pelajaran muatan lokal yang diikuti oleh siswa sesuai dengan pilihannya (Ma'as, 2016, p. 48).

\section{Perencanaan Pembelajaran}

Dalam Kurikulum 2013, terdapat perangkat-perangkat pembelajaran yang menjadi perencanaan pembelajaran yang wajib dimiliki guru karena mengajar tanpa menggunakan perangkat pembelajaran mengakibatkan guru tidak memiliki pedoman pembelajaran yang jelas. Adapun perangkat pembelajaran kurikulum sebagai berikut.

Pertama, Silabus. Silabus adalah rencana atau pedoman pelaksanaan pembelajaran pada suatu kelompok mata pelajaran tertentu yang mencakup standar kompetensi, kompetensi dasar, materi pokok pembelajaran, indikator pencapaian kompetensi untuk penilaian, penilaian, alokasi waktu, dan sumber belajar (Rianawati, 2008, p. 81). Jadi, silabus merupakan suatu rincian rencana mengajar yang disusun dalam kelompok mata pelajaran sebagai dasar dalam mengajar.

Silabus merupakan penjabaran lebih rinci dari Kompetensi Inti dan Kompetensi Dasar (KI-KD) yang minimal memuat kompetensi inti, kompetensi dasar, materi standar, metode pembelajaran, dan hasil belajar yang harus dimiliki oleh pasarta didik dalam suatu mata pelajaran tertentu. Sebelum pada umumnya sudah disiapkan oleh Badan Standar Nasional Pendidikan (BSNP), Direktorat Pendidikan Dasar dan Menengah, dan Pusat Kurikulum (Puskur). Namun, pengembangan terhadap komponen-komponen merupakan kewenangan guru, termasuk pengembangan 
format silabus. Semakin rinci silabus maka semakin memudahkan guru dalam menjabarkannya ke dalam rencana pelaksanaan pembelajaran bahkan merealisasikannya secara bertahap dalam pembelajaran (Mulyasa, 2018, p. 70).

Kedua, Rencana Pelaksanaan Pembelajaran (RPP). Rencana Pelaksanaan Pembelajaran (RPP) merupakan komponen penting dari kurikukulum. Rencana pelaksanaan pembelajaran (RPP) adalah rencana yang menggambarkan prosedur dan manajemen pembelajaran untuk mencapai satu atau lebih kompetensi dasar yang telah ditetapkan. Dengan RPP, seorang guru diharapkan bisa menerapkan pembelajaran secara terprogram (Rianawati, 2008, p. 86). Jadi, RPP merupakan hal yang wajib dipegang oleh guru dalam melaksanakan pembelajaran.

RPP pada hakikatnya merupakan perencanaan jangka pendek untuk memperkirakan dan memproyeksikan apa yang akan dilakukan dalam pembelajaran. Dengan kata lain, RPP merupakan upaya untuk memperkirakan tindakan yang akan dilakukan dalam kegiatan pembelajaran (Mulyasa, 2018, p. 108).

Ketiga, Program Tahunan. Program tahunan adalah rencana penetapan alokasi waktu satu tahun untuk mencapai tujuan yang telah ditetapkan. Program tahunan merupakan program umum dari setiap mata pelajaran untuk setiap kelas, berisi tentang garis-garis besar pengajaran yang hendak dicapai dalam satu tahun dan dikembangkan oleh guru. Program tahunan ini perlu disiapkan guru sebelum tahun ajaran baru dimulai, karena program tahunan dijadikan pedoman bagi pengembangan pendidikan selama proses pembelajaran yang akan dilaksanakan (Samsiyah, 2016, p. 100).

Keempat, Program Semester. Semester adalah satuan waktu yang digunakan untuk penyelenggaraan program pendidikan. Di Sekolah Dasar memiliki 2 semester yang masing-masing jangka waktunya selama 6 bulan dalam satu tahun. Dalam satu semester tersebut guru melaksanakan program, program semester adalah program yang berisikan garis-garis besar mengenai hal-hal yang akan dilaksanakan dan dicapai dalam satu semester dan program semester tersebut merupakan penjabaran dari program tahanunan (Samsiyah, 2016, p. 101).

Kelima, Buku Absensi. Buku absensi merupakan buku yang berisi daftar namanama dan keterangan mengenai kehadiran peserta didik dan diisi setiap hari untuk mengetahui tingkat kehadiran peserta didik.

Keenam, Evaluasi. Evaluasi dapat diartikan sebagai suatu proses menentukan hasil yang telah dicapai beberapa kegiatan yang direncanakan untuk mendukung tercapainya tujuan. Evaluasi dalam pembelajaran merupakan suatu proses untuk menentukan jasa, nilai, atau manfaat kegiatan pembelajaran melalui kegiatan penilaian atau pengukuran.

Agar evaluasi dapat akurat, maka evaluasi harus menerapkan prinsip-prinsip seperti: valid, berorientasi pada kompetensi, berkelanjutan, menyeluruh, bermakna, adil dan objektif, terbuka, iklhas, praktis, dicatat dan akurat (Rukajat, 2018, p. 1). Prinsip-prinsip tersebut harus berjalan dengat tepat karena menentukan sejauh mana hasil yang telah dicapai oleh siswa-siswi tiap mata pelajaran. 
Ketujuh, Kalender Pendidikan. Kalender pendidikan adalah pengaturan waktu untuk kegiatan pembelajaran peserta didik mulai dari setahun dalam waktu pelajaran efektif dan hari libur. Dengan kata lain, kalender pendidikan merupakan komponen alokasi waktu yang berfungsi memudahkan setiap orang supaya memulai perencanaan kegiatan pembelajaran ke depan melalui kalender pendidikan pada tahun ajaran yang berlaku (Andriani, 2018, p. 113).

\section{Pelaksanaan Pembelajaran}

Pelaksanaan pembelajaran berbicara mengenai waktu dan pengelolaan kelas. Alokasi waktu jam tatap muka pembalajaran pada tingkat pendidikan berbeda, seperti ("Peraturan Menteri Pendidikan dan Kebudayaan Republik Indonesia no 65," p. 8):

$\begin{array}{ll}\text { SD/MI } & : 35 \text { menit } \\ \text { SMP/MTs } & : 40 \text { menit } \\ \text { SMA/MA } & : 45 \text { menit } \\ \text { SMK/MAK } & : 45 \text { menit }\end{array}$

Pelaksanaan pembelajaran merupakan implementasi dari RPP meliputi kegiatan pendahuluan, inti dan penutup. Rencana Pelaksanaan Pembelajaran (RPP) merupakan komponen penting dari kurikukulum. Rencana Pelaksanaan Pembelajaran (RPP) adalah rencana yang menggambarkan prosedur dan manajemen pembelajaran untuk mencapai satu atau lebih kompetensi dasar yang telah ditetapkan. Dengan RPP, seorang guru diharapkan bisa menerapkan pembelajaran secara terprogram (Rianawati, 2008, p. 86).

Dalam RPP meliputi ("Peraturan Menteri Pendidikan dan Kebudayaan Republik Indonesia no 65," p. 9-10):

1) Kegiatan Pendahuluan. Dalam kegiatan pendahuluan, guru:

- Menyiapkan peserta didik secara psikis dan fisik untuk mengikuti proses pembelajaran

- Memberikan motivasi belajar siswa

- Mengajukan pertanyaan-pertanyaan

- Menjelaskan tujuan pembelajaran yang akan dicapai

- Menyampaikan cakupan materi dan penjelasan uraian kegiatan sesuai silabus

2) Kegiatan Inti. Kegiatan inti menggunakan model pembelajaran, metode pembelajaran, media pembelajaran, dan sumber pembelajaran yang disesuaikan dengan karakteristik peserta didik dan mata pelajaran. Dalam kegiatan inti, ada tiga poin penting yaitu:

- Sikap

- Pengetahuan

- Keterampilan

3) Penutup. Dalam kegiatan penutup, guru bersama siswa baik secara individual maupun kelompok melakukan refleksi untuk mengevaluasi: 
- Rangkaian aktivitas pembelajaran yang telah berlangsung

- Umpan balik terhadap proses dan hasil pembelajaran

- Menjadi informasi untuk mengetahui kegiatan pembelajaran pada pertemuan berikutnya

\section{Penilaian Hasil dan Proses Pembelajaran}

Penilaian proses pembelajaran menggunakan pendekatan penilaian autentik (authentic assessment) yang menilai kesiapan siswa, proses, dan hasil belajar secara utuh. Keterpaduan penilaian ketiga komponen tersebut akan menggambarkan kapasistas, gaya, dan perolehan belajar siswa atau bahkan mampu menghasilkan dampak instruksional dan dampak pengiring dari pembelajaran. Hasil penilaian otentik dapat digunakan oleh guru untuk merencanakan suatu perbaikan, pengayaan, atau pelayanan konseling. Evaluasi proses pembelajaran dilakukan saat proses pembelajaran dengan menggunakan alat: angket, observasi, catatan anekdot, dan refleksi ("Peraturan Menteri Pendidikan dan Kebudayaan Republik Indonesia no 65," p. 9).

\section{Perkembangan Spiritual}

Spiritual dalam Bahasa Inggris disebut dengan spirituality. Spirituality berasal dari kata spirit yang berarti roh atau jiwa. Spiritualitas mengandung pengertian hubungan manusia dengan Tuhannya, dan merupakan pengalaman atau keinginan mengenal Tuhan yang dilakukan secara pribadi dengan melihat sesuatu secara lebih dalam dan mencari pemahaman yang sesungguhnya (Imron, 2018, p. 27).

Agoes Dariyo dalam bukunya mengemukakan tentang pendapat James Fowler yaitu setiap tahap perkembangan manusia akan menetukan karakteristik tahap perkembangan keagamaan seseorang. Dengan mengetahui tahap perkembangannya, akan diketahui bagaimana memberikan langkah strategi pendidikan keagamaan secara tepat terhadap individu. Jadi kebutuhan kognitif dan emosional tidak dapat dipisahkan dalam perkembangan spiritual. Ada 6 tahap perkembangan spiritual menurut Fowler, yaitu: Intuitive-Projective Faith, Mythical-Literal Faith, SyntheticConvetional Faith, Individuating-Reflective Faith, Conjuctive Faith, dan Universalizing Faith (Dariyo, 2007, p. 13).

\section{Intuitive-Projective Faith}

Seseorang yang berada pada tahap ini berusaha memahami kekuatan yang mengatur (mengontrol) kehidupan dunia. Seseorang sering berimajinasi dan ciri khusus imajinasi masa ini ditandai dengan imajinasi yang irasional karena kapasitas kognitifnya yang masih bersifat preoperasional. Di mana pada masa ini mereka sering mengalami kesulitan untuk membedakan antara sebab-sebab suatu kejadian. Bila membicarakan Tuhan, yang tergambar dalam pikiran mereka adalah keharusan seseorang untuk patuh agar memperoleh ganjaran atau berkat (Dariyo, 2011, p. 90). 
Pada tahap ini terjadi kira-kira usia 4-8 tahun, di mana makna dibuat dan kepercayaan dibentuk secara intuitif dan dengan cara meniru. Dalam perjalanannya, seseorang mulai menemukan kenyataan yang melampaui pengalaman yang dirasakan sehari-hari dan saat itu juga mereka bertemu dengan batas-batas kehidupan, seperti kematian. Tetapi, kepercayaan tetap dialaskan kepada orangtua dan semua orang dewasa karena cara anak menerima pada tahap ini adalah meniru, oleh karena itu orangtua berperan penting dalam perkembangan spiritual anak (Groome, 2011, p. 101).

Intuitive-Projective Faith merupakan tahap perkembangan spiritual yang bersifat peniruan. Perkembangan spiritual ini merupakan hasil penggabungan dari hasil pengajaran dan contoh-contoh dari orang dewasa (Melyawanto dan Wilhemus, 2019, p. 73-86). Contohnya pengalaman kepercayaan seseorang akan Allah tergantung kepada siapa seseorang bergantung, pada umumnya orangtua akan memengaruhi gambaran tentang kepercayaan dan kepercayaan yang dianut oleh orangtua itu juga yang diyakini seorang anak, Seorang anak akan mengikuti apa yang dilakukan orangtuanya, seperti seorang anak yang melihat ayah dan ibunya selalu berdoa dan membaca Alkitab, maka anak tersebut pun akan mencoba untuk berdoa dan membaca Alkitab.

\section{Mythical-Literal Faith}

Anak-anak pada tahap ini sudah mulai mampu berpikir logis dan mulai mengembangkan suatu pandangan yang bersifat universal. Pada masa ini juga mereka langsung mengambil pemahaman harfiah terhadap pengalaman agama atau simbol-simbol agama. Anggapan mereka bahwa sifat-sifat Tuhan seperti figure orangtua. Jadi, Tuhan memberi penghargaan kepada yang berbuat baik, tetapi Dia akan menghukum orang yang berbuat jahat.

Tahap ini kira-kira terjadi pada usia 7-11 tahun, di mana seseorang datang untuk bergabung menjadi satu kelompok terdekatnya atau komunitas iman. Ini terjadi karena adanya kesadaran yang lebih besar mengenai perbedaan antara dirinya dan kumpulan orang-orang lain yang terdekat. Dengan adanya hal tersebut, maka membuat/membentuk makna dan kepercayaan sekarang lebih linier dan naratif daripada bersifat episodic seperti pada tahap pertama (Groome, 2011, p. 101).

Tahap Mythical-Literal Faith selaras dengan perkembangan kognitif, di mana seorang anak mulai memaknai tradisi masyarakat yang ada dan mulai berpikir logis (Melyawanto dan Wilhemus, 2019, p. 73-86). Contohnya dalam tahap ini, anak mulai menggabungkan diri dengan teman sebaya melalui sebuah geng yang dibuatnya dengan tujuan membentuk kepercayaan dalam dirinys. Selain itu, seseorang pada tahap ini memahami peran Allah itu digambarkan seperti penguasa, Tuhan akan menghadiahi orang baik dan akan menghukum orang yang jahat. 


\section{Synthetic-Convetional Faith}

Tahap ini biasanya terjadi pada usia 11 tahun ketika pengalaman seseorang semakin luas. Tahap ini dapat berlangsung lama sampai masa dewasa, dan untuk sejumlah orang, tahap ini bertahan hingga berkeluarga. Pada tahap ketiga ini bersifat menyesuaikan diri, di mana dalam tahap ini seseorang ingin merespons dengan setia pengharapan-pengharapan dan keputusan-keputusan orang-orang yang penting (Groome, 2011, p. 102).

Remaja telah mampu berpikir abstrak mulai dari bentuk ideologis sistem keyakinan/kepercayaan (belief system) dan komitmen sama hal-hal yang ideal. Karena, pada masa ini merupakan masa pencarian identitas diri, remaja mengharapkan hubungan pribadi yang bersifat intim dengan Tuhan. Dalam dirinya, tumbuh keyakinan untuk tunduk dan patuh terhadap yang diyakini dalam hatinya seperti yang dilakukan orang dewasa lainnya. Namun, ada kelemahannya yaitu belum mampu menganalisis alternatif ideologi agama secara tepat (Dariyo, 2011, p. 92).

Tahap Synthetic-Convetional Faith ditandai dengan adanya kesadaran simbolisme dan memiliki lebih dari satu cara guna mencari kebenaran. Di mana, kesadaran ini menjadikan seseorang berani dan mampu melakukan kritik atas ajaranajaran yang diberikan (Melyawanto dan Wilhemus, 2019, p. 73-86). Contohnya seseorang mulai mengandalkan Allah, dan mulai memahami bahwa Allah adalah seorang Pribadi yang mengenal dan memahami dirinya.

\section{Individuating-Reflective Faith}

Masa ini terjadi pada masa transisi antara remaja dan masa dewasa awal. Menurut Fowler, individu mampu mengambil dan melakukan tanggung jawab secara penuh terhadap yang diyakininya. Hal ini dilakukan karena mereka sadar dan merasa tahu secara sungguh-sungguh bahwa keyakinan itu sangat berarti dalam hidupnya, bahkan harus diperjuangkan dalam hidupnya (Dariyo, 2011, p. 93).

Peralihan dari tahap ketiga ke tahap empat adalah sangat penting terutama bagi kesinambungan perjalanan iman. Peralihan ini terjadi karena seseorang tidak tahan lagi menjadi "orang yang berbeda" ketika berada di kelompok yang berbeda. Seseorang mulai menyadari bahwa sekarang bertanggung jawab sendiri (Groome, 2011, p. 103).

Jadi, fase ini individu mulai mengambil tanggung jawab atas kepercayaan, perilaku, komitmen, dan gaya hidupnya. Tetapi di tahap ini setiap individu masih sangat membutuhkan figur yang bisa diteladani. Fowler menandai tahapan ini dengan adanya kesadaran terhadap pandangan dunia yang diberikan oleh orang lain dan setiap komitmen yang dipilih membantunya membentuk identitas diri (Idrus, 2006, p. 26-36). Contohnya seseorang sudah mampu memikul tanggung jawab atas apa yang dipilihnya. Namun, masih membutuhkan seorang figur yang dapat diteladani seperti orangtua. 


\section{Conjuctive Faith}

Iman tahap kelima melibatkan pemakaian kembali pola-pola komitmen dan cara-cara membuat makna masa lampau. Dengan maksud, memperoleh kembali kebenaran-kebenaran lama dengan cara yang baru. Jika tahap ketiga adalah tahap yang tergantung dan tahap keempat adalah tahap yang tergantung pada diri sendiri, maka tahap kelima adalah tahap yang saling tergantung di mana seseorang dapat bergantung pada orang lain tanpa kehilangan kebebasannya (Groome, 2011, p. 105). Contohnya seseorang mulai lebih terbuka terhadap pandangan-pandangan yang bertentangan.

\section{Universalizing Faith}

Pada tahap ini, diri sendiri berhenti menjadi dasar pegangan, dan hal-hal yang pokok diletakkan sebagai gantinya. Orang yang berada pada tahap ini tinggal di dunia sebagai orang yang hadir untuk mengubah. Dalam istilah spiritual, tahap keenam adalah keadaan penyatuan yang paling sempurna dengan Allah yang dapat dilakukan dalam kekekalan (Groome, 2011, p. 106).

Tahap Universalizing Faith memiliki ciri khas yaitu adanya desentrasi, di mana kemampuan untuk mencocokkan dan menyelaraskan perspektif dan pandangan dari orang lain yang masuk. Dalam konteks ini, seseorang akan berada pada pengenalan dunia melalui pengalaman dan tradisi religus orang lain sehingga seseorang dapat menerima banyak kebenaran dari banyak pandangan yang berbeda yang akan memperkaya, namun tidak akan menghilangkan titik pandang kebenaran. Contohnya seseorang memiliki rasa keutuhan pada kepercayaannya dan keinginan bertindak dengan benar bagi siapa pun, kapan pun, dan di mana pun. 
Tabel 1. Tahap Perkembangan Iman menurut James Fowler (Noor, 2018, p. 64)

Tahap

Tahap 1
Intuitive-Projective Faith

Tahap 2

Mythical-Literal Faith

Tahap 3

Synthetic-Conventional Faith

Tahap 4

Individuative-Reflective Faith

Tahap 5

Conjuctive Faith

Tahap 6

Universalizing Faith
Karakteristik

- Gambaran intuitif dari kebaikan dan kejahatan

- Fantasi dan kenyataan adalah sama

- Pemikiran logis dan konkrit

- Kisah-kisah agama diinterprestasikan secara harfiah

- Pemikiran lebih abstrak

- Menyesuaikan diri dengan keyakinan agama orang lain

- Bertanggung jawab terhadap keyakinan agama yang dianut

- Menjelajahi kedalaman pengalaman nilai dan keyakinan agama yang dianut

- Lebih terbuka terhadap pandangan yang paradoks dan bertentangan

- Kesadaran akan keterbatasan dan pembatasan

- Sistem kepercayaan yang dewasa

- Keadaan penyataan yang paling sempuran dengan Allah.

Kegiatan keagamaan dan pengalaman spiritual berkorelasi secara signifikan dengan tingkat kesehatan mental dan kebahagiaan. Artinya, semakin sering kegiatan keagamaan dilakukan maka semakin tinggi kemungkinan subjek tersebut untuk menjadi lebih bahagia dalam hidupnya (Mangestusi, 2017, p. 31).

Cooley dalam disertasi yang berjudul "Spiritual Assessment of Students at Conservativ Wesleyan," mengemukakan bahwa perubahan spiritual yang terjadi membentuk tatanan hidup seseorang. Di mana, perubahan tersebut harus mampu membuat seseorang hidup semakin serupa dengan Kristus. Perubahan spiritual mencakup pada perubahan kognitif, komitmen, karakter, komunikasi, kasih, dan kompetensi (Cooley, 2011, p. 178).

Dengan berbagai pendapat yang mengemukakan mengenai spiritual maka dapat diartikan bahwa perkembangan spiritual adalah bagian penting dari kehidupan setiap individu, di mana setiap individu memiliki kepercayaan yang dihubungkan dengan agama dan berdampak penting bagi kehidupan setiap individu.

Perkembangan berbicara tentang sebuah perubahan yang terjadi pada anak. Setiap perubahan yang terjadi diharapkan merupakan perubahan yang baik bagi anak dan membawa pengaruh yang baik bagi masa depannya. Ada satu hal yang sangat penting dari keberhasilan seorang anak, yaitu Spiritual Quotient. Berbicara 
tentang spiritual quotient berarti membahas tentang perilaku individu yang sesuai dengan hatinya atau perbuatan yang berdasarkan kesadaran terhadap Allah yang menciptakan alam semesta (Kasdu, 2004, p. 7).

Berbicara tentang spiritual, tentu sangat berkaitan erat dengan firman Tuhan. Markus 10:13-16 menunjukkan bahwa anak-anak kecil sangat berharga di mata Yesus meskipun di mata orang dewasa (yang ditunjukkan oleh murid-murid) dilihat sebagai yang lemah, tidak memiliki pengaruh, bahkan secara umum sangat bergantung pada orangtua. Namun, ada penghargaan yang diberikan oleh Yesus kepada anak-anak, bahkan bukan hanya sekadar penghargaan melainkan ada tindakan Yesus, yaitu memeluk, meletakkan tangan, bahkan memberkati mereka. Sikap dan tindakan Yesus menyatakan bahwa keberadaan anak-anak harus diakui dan dihargai sesuai dengan perkembangan usia dan kemampuannya (Prasetya, 2008, p. 6).

Perkembangan spiritual tidak terlepas dari pendidikan iman, dan pendidikan iman sebaiknya dilakukan sejak dini kepada anak. Pendidikan iman yang diberikan kepada anak sangat menentukan keberadaan dan kehidupan mereka di masa depan, baik yang menyangkut kehidupan pribadi, kehidupan sosial, kehidupan beriman, maupun panggilan hidupnya (Prasetya, 2008, p. 17).

Hasil penelitian ilmiah di bidang Neurologi menyatakan bahwa perkembangan kecerdasan anak pada usia:
a. $0-4$ tahun mencapai $50 \%$
b. $0-8$ tahun mencapai $80 \%$
c. $0-18$ tahun mencapai $100 \%$

Sedangkan pertumbuhan fisik otak anak pada usia:

a. 0 tahun mencapai $25 \%$

b. 6 tahun mencapai $85 \%$

c. 12 tahun mencapai $100 \%$

Berdasarkan hasil penelitian tersebut bahwa usia dini merupakan usia yang sangat penting bagi perkembangan anak yang berkesinambungan. Dengan demikian maka masa emas terletak pada anak usia dini, dan pada masa itulah orangtua atau guru dituntut untuk harus menstimulasi perkembangan kecerdasan anak untuk membentuk karakter yang mulia. Meskipun demikian karakter emas tidak akan terbentuk secara optimal apabila hanya distimulasi pada usia dini saja. Oleh karena itu usia dini memang sangat penting akan tetapi jangan sampai mengabaikan usia selanjutnya. Dengan kata lain, usia dini menjadi dasar pembentukan yang tepat (Kertamuda, 2015, p. 4).

\section{Faktor-Faktor yang Memengaruhi Perkembangan Spiritual}

Berhasilnya perkembangan spiritual dapat dilihat dari tingkat pemahaman kehendak Tuhan dalam kehidupan setiap pribadi. Jadi, semakin tinggi tingkat kecerdasan spiritualnya, maka semakin ia dapat memahami kehendak Tuhan dalam setiap langkah kehidupannya. Untuk memperjelas, ada 3 hal yang diperhatikan, yaitu: 
tingkat kepekaan mendengar suara Tuhan, tingkat ketajaman cara pandang paradigma llahi, dan tingkat pengenalan karakter kuasa dan hati Tuhan (Yuwono, $2010,78)$. Ada beberapa faktor yang memengaruhi perkembangan spiritual.

\section{Pembawaan}

Pembawaan adalah pembentukan kepribadian yang merupakan warisan genetik dari kedua orangtua berupa intelektual seperti pola pikir, penalaran, fantasi, pengalaman atau pemecahan masalah (Aisyah, 2015, p. 24). Jadi, setiap manusia yang lahir mempunyai potensi beragama atau memiliki kayakinan kepada Tuhan dipengaruhi oleh pembawaan dari luar dirinya yang mengatur hidup dan kehidupannya. Potensi beragama ini paling banyak atau paling kuat dipengaruhi oleh orangtua.

\section{Lingkungan}

Lingkungan merupakan faktor penentu dalam perkembangan. Lingkungan fisik adalah lingkungan alam dimana peserta didik berada yang secara langsung memberikan pengaruh dalam pola hidup. Sedangkan, lingkungan psikologis adalah hal yang menyangkut persepsi, berpikir, perasaan, atau cara pandangan mengenai dunia sekitarnya (Aisyah, 2015, p. 29). Lingkungan yang memengaruhi perkembangan spiritual anak antara lain:

\section{Lingkungan Keluarga}

Keluarga adalah lingkungan pertama anak, di lingkungan keluarga pertamatama anak mendapatkan pengaruh secara sadar. Karena itu keluarga merupakan pendidikan tertua, yang bersifat informal. Ayah dan ibu sebagai penentu dan pendidik bagi anak-anak (Aisyah, 2015, p. 56). Lingkungan keluarga sangat penting bagi kehidupan dan perkembangan spirirtual, keluarga merupakan basis utama ketika seorang anak lahir ke dunia dan juga lingkungan primer bagi dasar keterampilan, kecerdasan dan nilai-nilai agama. Untuk itu orangtua perlu menjadi lembaga yang berkompeten untuk mendidik dan membentuk anak (Susilo, 2006, p. 13).

\section{Lingkungan Sekolah}

Guru-guru di Lembaga pendidikan formal adalah orang dewasa yang mendapat kepercayaan dari pemerintah untuk menjalankan tugas sebagai pendidik. Karena orangtua tidak mampu memberikan pendidikan lanjutan dalam bentuk berbagai pengetahuan dan keterampilan atau kecakapan hidup, maka dibutuhkan Lembaga sekolah. Tugas sekolah menjadi sangat penting dalam menyiapkan anak-anak dalam kehidupan masyarakat (Aisyah, 2015, p. 59). 


\section{Lingkungan Masyarakat}

Masyarakat adalah salah satu lingkungan pendidikan yang pengaruhnya sangat besar terhadap perkembangan pribadi seoarang individu. Peranan masyarakat adalah ikut membantu menyelenggarakan atau usaha sadar yang memberi kemungkinan perkembangan sosial, budaya, keagamaan, kepercayaan, keahlian, keterampilan, yang dapat dimanfaatkan oleh penduduk (Aisyah, 2015, p. 6). Lingkungan masyarakat merupakan lingkungan di mana seorang anak keluar dari lingkungan keluarganya. Seorang anak akan bertemu dengan orang lain dan mulai beradaptasi dengan nilainilai yang ada dalam lingkungan tersebut. Hal itu membuat anak menimba nilai-nilai yang ada dan hidup dalam lingkungan masyarakat termasuk nilai keagamaan (Susilo, 2006, p. 14).

\begin{tabular}{|c|c|}
\hline Manajemen Kurikulum 2013 & Perkembangan Spiritual \\
\hline$\downarrow$ & $\downarrow$ \\
\hline $\begin{array}{l}\text { 1. Perencanaan Pembelajaran } \\
\text { 2. Pelaksanaan Pembelajaran } \\
\text { 3. Penilaian hasil dan proses } \\
\text { Pembelajaran }\end{array}$ & $\begin{array}{l}\text { 1. Intuitive-Projective Faith } \\
\text { 2. Mythical-Literal Faith } \\
\text { 3. Synthetic-Convetional } \\
\text { Faith } \\
\text { 4. Individuating-Reflective } \\
\text { Faith } \\
\text { 5. Conjunctive Faith } \\
\text { 6. Universalizing Faith }\end{array}$ \\
\hline
\end{tabular}

Gambar 1. Hubungan Kurikulum 2013 terhadap Perkembangan Spiritual Anak

\section{METODE}

\section{Jenis Penelitian dan Partisipan}

Jenis penelitian yang di gunakan oleh penulis adalah penelitian secara kuantitatif (Serli dan Wijaya, 2020, p. 23; Sareong dan Supartini, 2020, p. 36). Di mana, untuk melalukan metode penelitian tersebut maka dilakukan beberapa hal yaitu pertama, pengambilan dan pengumpulan data melalui buku, jurnal, dan artikel. Kedua, penyembaran angket. Ketiga, wawancara secara langsung untuk memperkuat hasil dari angket. Metode penelitian kuantitatif adalah penelitian yang berlandaskan pada filsafat positivisme, digunakan untuk meneliti pada populasi atau sampel tertentu, dalam penelitian ini yang menjadi populasi adalah siswa-siswi kelas 4 dan 5 SD Kristen Kalam Kudus dengan jumlah populasi yaitu 40 siswa. Dalam menentukan sampel, penulis menggungakan sampling sistematis yaitu teknik pengambilan sampel 
berdasarkan urutan anggota dari anggota yang telah diberi nomor urut. Dari 40 populasi diberi nomor urut, yaitu 1-40 dan pengambilan sampel dilakukan dengan nomor genap saja maka sampelnya berjumlah 20 orang.

Subjek penelitian antara lain 20 responden dari kelas IV dan V dengan jumlah 12 siswa kelas V dan 8 siswa yang berada di kelas IV.

Tabel 2. Profil Siswa

\begin{tabular}{ccc}
\hline Usia & Jumlah (orang) & Persentase (\%) \\
\hline 10 tahun & 9 & $45 \%$ \\
9 tahun & 11 & $55 \%$ \\
Total & 20 & $100 \%$ \\
\hline
\end{tabular}

\section{Teknik Analisis Data}

Teknik analisis data yang digunakan penulis yaitu Rating Scale. Dengan menggunakan Rating Scale, data mentah yang diperoleh berupa angka kemudian ditafsirkan dalam pengertian kualitatif. Dalam skala model Rating Scale, responden tidak akan menjawab salah satu dari jawaban kualitatif yang telah disediakan tetapi menjawab salah satu jawaban kuantitatif yang telah disediakan.

Untuk perhitungan korelasi variabel $\mathrm{X}$ dan $\mathrm{Y}$, penulis menggunakan uji korelasi Pearson Product Moment. Dengan rumus:

$r_{x y}=\frac{n \sum X Y-\left(\sum X\right)\left(\sum Y\right)}{\sqrt{\left\{n \sum X^{2}-\left(\sum X\right)^{2}\right\}\left\{n \sum Y^{2}-\left(\sum Y\right)^{2}\right\}}}$

Keterangan (Widiyanto, 2014, p. 229):

$r \quad$ : koefisien korelasi

n : jumlah data

$\sum X \quad$ : jumlah skor variabel $X$

$\sum Y \quad$ : jumlah skor variabel $Y$

\section{HASIL DAN PEMBAHASAN}

Hasil yang didapatkan pada indikator perencanaan pembelajaran dalam manajemen kurikulum yang dilaksanakan telah berjalan dengan sangat baik (berada pada skala selalu, 498 atau $88 \%$ ). Hal tersebut juga dikuatkan oleh salah satu guru PAK yang ada, dengan mengatakan bahwa (Marsita, 2019):

Sebelum mengajar harus benar-benar mempersiapkan diri dan menyiapkan silabus karena silabus itu sangat penting sebagai pedoman dalam mengajar. Dan tentu juga harus memperhatikan yang namanya kehadiran siswa untuk melihat 
bagaimana tingkat kehadiran siswa dalam sekolah untuk itu absen juga harus dijalankan. Itu merupakan tugas dan tanggung jawab seorang guru yang tidak boleh diabaikan.

Pada indikator pelaksanaan pembelajaran yang dilaksanakan telah berjalan dengan sangat baik (berada pada skala selalu, 501). Hasil tersebut dikuatkan dengan wawancara salah satu siswa (Christian, 2019):

Sebelum saya mengikuti pelajaran, saya harus mempersiapkan diri saya agar saya dapat menerima pelajaran dengan baik. Di sekolah juga, kami belajar untuk disiplin untuk itu saya harus masuk kelas tepat waktu.

Seorang guru PAK mengatakan bahwa (Marsita, 2019):

Karena di sekolah ini menekankan kedisiplinan, maka dari itu yang harus terlebih dahulu harus tepat waktu adalah guru. Karena guru menjadi contoh dari setiap murid yang ada. Apabila guru terlambat maka sangat diperhatikan oleh siswasiswi dan kemungkinan besar akan diikuti oleh siswa.

Pada indikator penilaian hasil dan proses pembelajaran yang telah dilaksanakan berada pada skala sering yang berarti berjalan dengan baik. Hal ini dikuatkan oleh salah satu siswa yang mengatakan bahwa (Rennifer, 2019):

Di dalam kelas, jika guru bertanya saya sangat suka dan sering menjawab. Dan saya juga bisa menyampaikan apa pendapat saya jika tidak sesuai dengan pendapat teman-teman saya. Dan karena cara guru mengajar menyenangkan jadi saya bisa mengingat materi yang diajarkan.

Tabel 3. Hasil Tiap Responden untuk Perkembangan Spiritual

\begin{tabular}{c|cccccc}
\hline \multirow{3}{*}{ Jum } & \multicolumn{6}{|c}{ Indikator } \\
\cline { 2 - 7 } Res & $\begin{array}{c}\text { Intuitive- } \\
\text { Projective } \\
\text { Faith }\end{array}$ & $\begin{array}{c}\text { Mythical- } \\
\text { Literal } \\
\text { Faith }\end{array}$ & $\begin{array}{c}\text { Synthetic- } \\
\text { Convetio- } \\
\text { nal Faith }\end{array}$ & $\begin{array}{c}\text { Individuating- } \\
\text { Reflective } \\
\text { Faith }\end{array}$ & $\begin{array}{c}\text { Conjunctive } \\
\text { Faith }\end{array}$ & $\begin{array}{c}\text { Universalizing } \\
\text { Faith }\end{array}$ \\
\hline 20 & - & - & - & - & 8 & 12
\end{tabular}

Dari 20 responden, 12 responden berada pada tahap Universalizing Faith dan 8 responden berada pada tahap Conjunctive Faith. Jadi, dari hasil penelitian ini hanya terdapat dua tahap saja dari enam tahap perkembangan spiritual yang menjadi indikator pembahasan.

Conjunctive Faith $\quad=\frac{8}{20}=0,4=40 \%$

Universalizing Faith $=\frac{12}{20}=0,6=60 \%$ 
Dari 20 responden, 8 di antaranya berada pada tahap Conjunctive Faith. Conjunctive Faith merupakan perkembangan tahap ke 5 dalam perkembangan spiritual. Di mana, pada tahap ini responden mulai semakin menyadari hal-hal yang ada dalam diri mereka, dan tahap ini responden masih bergantung pada orang lain (orangtua) namun tetap dalam komitmen sendiri untuk mencapai tahap selanjutnya.

Hasil ini dikuatkan dengan wawancara penulis kepada siswa yang berada pada tahap ini (Jane, 2019):

Awalnya saya beragama Kristen karena orangtua saya Kristen, tapi ketika saya ikut sekolah minggu saya belajar jika saya ikut Yesus bukan karena ikut-ikutan tapi karena saya memang cinta Yesus dan saya mau ikut Tuhan untuk itu sekarang saya tidak Kristen karena ikut-ikutan lagi.

Dikuatkan juga dengan pendapat salah satu siswa yang mengatakan (Mattew, 2019):

Keluarga saya semuanya Kristen, papa, mama, kakak, semuanya Kristen dan dari kecil saya diajarkan untuk percaya Yesus dan awalnya saya hanya ikut mereka ke gereja tetapi lama-lama saya sudah mulai mengerti meskipun tidak sepenuhnya saya mengerti.

Dari 20 responden, 12 di antaranya berada pada tahap Universalizing Faith. Universalizing merupakan perkembangan tahap ke 6 atau tahap terakhir dalam perkembangan spiritual. Di mana responden tidak lagi bergantung tetapi sudah memiliki dasar sendiri dalam kepercayaan yang dipilihnya.

Hasil ini dikuatkan dengan wawancara penulis kepada siswa yang berada pada tahap ini (Belinda, 2019 dan Christian, 2019):

Saya dari kecil diajak oleh orangtua untuk ke gereja, dan semakin hari saya semakin rajin ke gereja ikut sekolah minggu. Di sekolah minggu saya di ajar banyak hal mengenai Juruselamat, di rumah juga orangtua saya selalu mengajarkan saya kebaikan dan memiliki waktu khusus dengan Tuhan meskipun awalnya saya tidak tau tapi papa selalu mencoba jelaskan.

Saya lahir di keluarga yang agamanya Kristen, jadi dari kecil selalu di ajar tentang Yesus. Saya diikutkan sekolah minggu, rabu gembira, dan kegiatan-kegiatan gereja, diajar pimpin doa, diajar baca Alkitab setiap hari, dan masih banyak. Dan lingkungan saya juga kebanyakan orang Kristen.

Untuk hasil dan pembahasan, yaitu: pertama, indikator perencanaan pembelajaran dan pelaksanaan pembelajaran yang dilaksanakan telah berjalan dengan sangat baik dan penilaian hasil pembelajaran dalam manajemen kurikulum yang dilaksanakan telah berjalan. Hal tersebut terjadi karena guru dan siswa telah melakukan komponen-komponen yang terdapat pada setiap indikator dengan baik. Kedua, dari 20 responden yang ada, 8 responden berada pada tahap Conjunctive Faith. Conjunctive Faith merupakan perkembangan tahap ke 5 dalam perkembangan 
spiritual. 12 di antaranya berada pada tahap Universalizing Faith. Universalizing merupakan perkembangan tahap ke 6 atau tahap terakhir dalam perkembangan spiritual. Dari wawancara yang dilakukan, maka hasil ini dikuatkan oleh pernyataan para responden. Di mana, spiritual responden dibentuk mulai sejak kecil dan sangat dipengaruhi oleh keluarga dan gereja. Ketiga, menurut hasil wawancara terhadap beberapa responden, aspek spiritual responden lebih didukung oleh faktor keluarga dan gereja. Jadi, keluarga sangat berperan penting dalam pembentukan perkembangan spiritual anak karena keluarga merupakan lingkungan pertama anak untuk belajar, dan anak tentu akan meniru kedua orangtuanya. Selain itu keluarga, gereja juga memiliki peran penting dalam pembentukan perkembangan spiritual anak.

\section{KESIMPULAN}

Dari hasil analisis yang telah dilakukan dalam penelitian ini dapat disimpulkan bahwa manajemen kurikulum 2013 yang telah dilaksanakan di SD Kristen Kalam Kudus Makassar (perencanaan pembelajaran, pelaksanaan pembelajaran, dan penilaian hasil dan proses pembelajaran) terlaksana dengan sangat baik. Dalam penelitian ini juga menunujukkan bahwa siswa-siswi yang menjadi responden pada penelitian ini berada pada tahap Conjunctive Faith dan Universalizing Faith. Di mana, dari 6 tahap yang ada hanya ada 2 tahap yang menjadi hasil dari penelitian yang dilakukan oleh penulis. Dalam penelitian ini menunujukkan bahwa pengaruh variabel $X$ terhadap variabel $Y$ berada pada angka yang lemah yang memberi arti bahwa variabel (perencanaan, pelaksanaan, dan penilaian hasil dan proses pembelajaran) memberikan kontribusi data pengaruh lemah terhadap perkembangan spiritual anak, oleh karena itu dapat disimpulkan bahwa perkembangan anak dipengaruhi oleh variabel yang lain.

\section{KEPUSTAKAAN}

(2013). Peraturan Menteri Pendidikan dan Kebudayaan Republik Indonesia no 65.

https://luk.staff.ugm.ac.id/atur/bsnp/Permendikbud65-2013SI.pdf.

Aisyah, Siti. (2015). Perkembangan Peserta Didik dan Bimbingan Belajar. Yogyakarta: Deepublish.

Andriani, Ayu. (2018). Praktis Membuat Buku Kerja Guru. Sukabumi: CV Jejak.

Cooley, Thimoty L. (2011). "Spiritual Assessment of Students at Conservativ Wesleya Arminian Bible Colleges." Dissertation, Ph.D, Columbia International University.

Dariyo, Agoes. (2007). Psikologi Perkembangan Anak Tiga Tahun Pertama. Bandung: Refika Aditama.

Groome, Thomas H. (2011). Christian Religious Education-Pendidikan Agama Kristen: Berbagi cerita dan Visi Kita. Jakarta: BPK Gunung Mulia. 
Gunawan, Imam, dan Djum Djum Noor Benty. (2017). Manajemen Pendidikan Suatu Pengantar Praktik. Bandung: Alfabeta.

Idrus, Muhammad. (Januari 2006). Keraguan Kepada Tuhan Pada Remaja. Jurnal

Psikologika, 11(21), 27-34.

https://journal.uii.ac.id/Psikologika/article/view/280/7380.

Imron. (2018). Aspek Spiritualitas dalam Kinerja. Magelang: UNIMMA PRES.

Kasdu, Dini. (2004). Anak cerdas. Jakarta: Puspa Swara.

Kertamuda, Miftahul Achyar. (2015). Golden Age: Strategi Membentuk Karakter Emas pada Anak Sejak Usia Dini. Jakarta: IKAPI.

Ma'as, Shobirin. (2016). Konsep dan Implementasi Kurikulum 2013 Di Sekolah Dasar.

Yogyakarta: Deepublish.

Mangestusi, Retno. (2017). Pengembangan Spiritualitas Remaja: Mengapa Remaja

Laki-laki Lebih Memerlukan Dukungan Keluarga Dalam Pengembangan

Spiritualitas. Jurnal Psikoislamika, 14(1), 31-36. http://ejournal.uin-

malang.ac.id/index.php/psiko/article/view/6500.

Melyawanto, Dicky, dan Ola Rongan Wilhemus. (April 2019). Pengaruh Pembelajaran

Pendidikan Agama Katolik Terhadap Perkembangan Iman Dan Perubahan

Perilaku Siswa Sekolah Menengah Pertama Katolik Di Kota Madiun. JPAK: Jurnal

Pendidikan Agama Katolik, 19(1), 73-86.

https://doi.org/10.34150/jpak.v19i1.142.

Mulyasa. (2018). Implementasi Kurikulum 2013 Revisi. Jakarta: Bumi Aksara.

Noor, Triana Rosalina. (2018). Remaja Dan Pemahaman Agama. Jurnal Pendidikan

Islam, 3(2), 54-68. http://www.riset.unisma.ac.id/index.php/fai/article/view/1639.

Prasetya, L. (2008). Dasar-Dasar Pendampingan Iman Anak. Yogyakarta: Kanisius.

Puspitasari, Rety. (Oktober 2015). Pengaruh Pola Asuh Disiplin Dan Pola Asuh

Spiritual Ibu Terhadap Karakter Anak Usia Sekolah Dasar. Jurnal Pendidikan

Karakter, 5(1), 208-216.

https://journal.uny.ac.id/index.php/jpka/article/viewFile/8624/7117

Rianawati. (2008). Implementasi Nilai-Nilai Karakter pada Mata Pelajaran Pendidikan

Agama Islam (PAI). Pontianak: IAIN Pontianak Press.

Rukajat, Ajat. (2018). Teknik Evaluasi Pembelajaran. Yogyakarta: Deepublish.

Samsiyah, Nur. (2016). Pembelajaran Bahasa Indonesia Di SD Kelas Tinggi. Magetan: Media Grafika.

Sareong, Irene Priskila dan Tri Supartini. (2020). Hubungan Komunikasi Interpersonal

Guru dan Siswa Terhadap Keaktifan Belajar Siswa di SMA Kristen Pelita Kasih

Makassar. Jurnal Ilmu Teologi dan Pendidikan Agama Kristen, 1(1), 29-42. DOI: 10.25278/jitpk.v1i1.466.

Serli dan Hengki Wijaya. (2020). Metode Permainan Dalam Meningkatkan

Pemahaman Firman Tuhan pada Remaja GKII Okahapi Sumba Timur. Jurnal Ilmu

Teologi dan Pendidikan Agama Kristen, 1(1), 17-28. DOI: 10.25278/jitpk.v1i1.459.

Supriyanto, Agus. (2016). Collaboration Counselor and Parent for Developing Student

Spiritual Competency trough Comprehensive Guidance and Counseling Service. 
Jurnal Fokus Konseling, 2(1), 48-50.

https://pdfs.semanticscholar.org/64c0/86274a05b3fc98df6ecee3350009f003acfa .pdf.

Susilo, Johannes Dicky. (April 2006). Perkembangan Religiositas Remaja Akhir. Insan, $8(1), 12-20$.

journal.unair.ac.id/filerPDF/02\%20\%20Perkembangan\%20Religiositas\%20Remaj a\%20Akhir.pdf.

Widiyanto, Mikha Agus. (2014). Statistika. Bandung: Kalam Hidup.

Yuwono, Budi. (2010). SQ Reformation. Jakarta: Gramedia Pustaka Utama.

\section{Wawancara}

Belinda, Gabriela. Wawancara Oleh Penulis. Makassar, 5 Agustus 2019.

Christian, Lionel. Wawancara Oleh Penulis. Makassar, 5 Agustus 2019.

Jane, Vania. Wawancara Oleh Penulis. Makassar, 5 Agustus 2019.

Marsita, Mersi. Wawancara Oleh Penulis. Makassar, 19 Juli 2019.

Mattew. Wawancara Oleh Penulis. Makassar, 5 Agustus 2019.

Rennifer. Wawancara Oleh Penulis. Makassar, 5 Agustus 2019. 